\title{
Multi-Element Imaging of a 1.4 Ga Authigenic Siderite Crystal
}

\author{
Huajian Wang ${ }^{1, *}$, Yuntao Ye ${ }^{1,2}$, Yan Deng ${ }^{1,2}$, Yuke Liu ${ }^{1}$, Yitong Lyu ${ }^{1}$, Fenglian Zhang ${ }^{1,3}$, Xiaomei Wang ${ }^{1}$ \\ and Shuichang Zhang ${ }^{1}$ \\ 1 Research Institute of Petroleum Exploration and Development, Beijing 100083, China; \\ yeyuntao@pku.edu.cn (Y.Y.); dengy@pku.edu.cn (Y.D.); liuyuke@petrochina.com.cn (Y.L.); \\ lyt2020@petrochina.com.cn (Y.L.); zhangfl_0163@163.com (F.Z.); wxm01@petrochina.com.cn (X.W.); \\ sczhang@petrochina.com.cn (S.Z.) \\ 2 School of Earth and Space Sciences, Peking University, Beijing 100871, China \\ 3 School of Earth Sciences and Resources, China University of Geosciences (Beijing), Beijing 100083, China \\ * Correspondence: wanghuajian@petrochina.com.cn; Tel.: +86-010-8359-5538
}

check for updates

Citation: Wang, H.; Ye, Y.; Deng, Y.; Liu, Y.; Lyu, Y.; Zhang, F.; Wang, X.; Zhang, S. Multi-Element Imaging of a $1.4 \mathrm{Ga}$ Authigenic Siderite Crystal. Minerals 2021, 11, 1395. https:// doi.org/10.3390/min11121395

Academic Editors: Yufeng Guo, Shuai Wang, Mao Chen, Kexin Jiao, Lingzhi Yang, Feng Chen,

Fuqiang Zheng and Alexandre V. Andronikov

Received: 5 November 2021 Accepted: 7 December 2021 Published: 9 December 2021

Publisher's Note: MDPI stays neutral with regard to jurisdictional claims in published maps and institutional affiliations.

Copyright: (c) 2021 by the authors. Licensee MDPI, Basel, Switzerland. This article is an open access article distributed under the terms and conditions of the Creative Commons Attribution (CC BY) license (https:/ / creativecommons.org/licenses/by/ $4.0 /)$.
Abstract: Iron formations (IFs) are traditionally considered to be limited during $1.8-0.8 \mathrm{Ga}$. However, there are recent reports of siderite-dominated IFs within this time interval, such as the $1.40 \mathrm{Ga}$ Xiamaling IF in North China and the $1.33 \mathrm{Ga}$ Jingtieshan IF in Qilian. To further explore the crystallization and formation mechanisms of siderite, an authigenic siderite crystal from the Xiamaling IF was fully scanned using laser ablation inductively coupled plasma mass spectrometry (LA-ICPMS). Multi-element imaging with a spatial resolution of $5 \mu \mathrm{m}$ revealed an obvious rim structure of the siderite crystal, which might record the crystallization and growth processes. The Al- and Fe-enriched zone in the core of siderite crystal might be an iron-bearing nucleus, and the formation of rim structure was related to the transition from a closed crystallization environment to a semi-closed growth environment. These results, combined with carbon isotope evidence from the siderites and surrounding shales, suggest that vigorous dissimilatory iron reduction that can provide $\mathrm{Fe}^{2+}$ and $\mathrm{HCO}_{3}{ }^{-}$to the pore water is a key factor to form the siderite-dominated Xiamaling IF.

Keywords: siderite; iron; crystallization; multi-element imaging; LA-ICP-MS; Mesoproterozoic; Xiamaling Formation; dissimilatory iron reduction

\section{Introduction}

Most marine massive iron formations (IFs) were deposited during 3.0-1.8 Ga, with a brief return around $0.8 \mathrm{Ga}$ [1]. During the one billion-year gap between 1.8 and $0.8 \mathrm{Ga}$, the IFs shortage is thought to be a result of significantly decreased $\mathrm{Fe}^{2+}$ concentration in the ocean, which was either substantially oxidized [2] or sulfurized [3]. Recent studies provide increasing evidence that ferruginous water was widespread in the deep ocean until $0.58 \mathrm{Ga}[4,5]$. Several Mesoproterozoic IFs have also been reported, such as the $1.40 \mathrm{Ga}$ Xiamaling IF in North China [6,7] and the 1.33 Ga Jingtieshan IF in Qilian [8]. However, different to the hematite- and magnetite-dominated 3.0-1.8 Ga IFs [9], the Xiamaling and Jingtieshan IFs are dominated by siderite [6-8]. In Australia, massive siderite deposits have also been found in the $\sim 1.45 \mathrm{Ga}$ Sherwin ironstone [10] and 2.5 Ga Hamersley IF [11]. Therefore, it is of great importance to explore the crystallization and formation mechanisms of siderite in the Precambrian ocean.

Siderite is a common Fe-bearing mineral, with $\mathrm{FeCO}_{3}$ as the main component. It is a calcite group of minerals, and its standard crystal form is mostly rhombohedral [12,13]. Siderite usually forms in specific conditions with either a hydrothermal origin or a diagenetic origin. Hydrothermal siderite is common in metallic veins and associated with sphalerite, barite, and other minerals $[14,15]$. Diagenetic siderite is mostly found in sedimentary rocks, such as clastic rocks [6], carbonate rocks [16], iron-beds [17], and coal [18]. Compared to the siderite formed in fresh water [19], the siderite in geological records is 
usually not pure, due to the substitution of $\mathrm{Mn}, \mathrm{Mg}$, and Ca for Fe [20,21]. Accompanied by substitution and growth, the primary siderite crystals can further transform into rhombohedral and/or massive siderite in the sediment [22].

In addition to the required water conditions, siderite formation also depends on the crystal nucleus and fluid saturation state [12]. Thus, authigenic siderite is mostly formed through biochemical reactions with reduction of iron-bearing minerals and oxidation of organic matter to provide $\mathrm{Fe}^{2+}$ and $\mathrm{HCO}_{3}{ }^{-}[1,6,23]$. The spheroidal siderite crystals formed in the ferruginous water column or pore water in response to the reactions of Fe-oxides and organic matters [21] have been considered as primary precipitates and precursors for rhombohedral and cemented diagenetic siderites in Precambrian rocks [22]. According to the diagenetic stages, the formation of authigenic siderite can be divided into three steps: (1) generation of colloidal aggregates with crystal nucleus; (2) generation of spherulites with poorly developed rim structures; (3) generation of oolites and rhombohedrons with well-developed rim structures [21]. The growth of siderite crystals always accompanies elemental substitution and mineral transformation, leading to varied morphologies and elemental compositions in different diagenetic stages. Therefore, petrological, mineralogical, and geochemical analyses of authigenic siderite are important for revealing the crystallization and formation mechanisms of siderite [24-26].

For the Xiamaling and Jingtieshan IFs, previous studies have already implemented detailed petrological, mineralogical, and geochemical analyses $[6-8,27,28]$. However, research on the crystallization process of the Mesoproterozoic siderite has not been reported yet. In this study, laser ablation inductively coupled plasma mass spectrometry (LA-ICP-MS) is used for in situ multi-element imaging of an authigenic siderite crystal collected from the Xiamaling IF.

\section{Geological Setting}

The Xiamaling IF is distributed in the Yanliao Basin, which is located at the north margin of the North China Craton (Figure 1a-c). Paleo- and Mesoproterozoic sediments are found in the Yanliao Basin with a maximum thickness of ca. $8000 \mathrm{~m}$ [29]. The Xiamaling Formation is mainly composed of shale and siltstone and deposited over the carbonate rocks of the Tieling Formation with a parallel unconformity [30,31]. Two zircon U-Pb TIMS ages of 1384.4 $\pm 1.4 \mathrm{Ma}$ and $1392.0 \pm 1.0 \mathrm{Ma}$ [30] and a zircon U-Pb LA-ICP-MS age of 1418 $\pm 14 \mathrm{Ma}$ [31] have been obtained from the volcanic ash layers in the middle and bottom of the Xiamaling Formation, respectively (Figure 1d). In addition, abundant baddeleyite $\mathrm{U}-\mathrm{Pb}$ ages of ca. $1320 \mathrm{Ma}$, obtained from the intruded gabbro-diabase sills in the Xiamaling sediments, are considered to be accompanied by a pre-magmatic uplift that started at ca. $1350 \mathrm{Ma}$ [32], which further constrain the minimum age of Xiamaling Formation should be older than 1350 Ma.

On the basis of the detailed geochemical and sedimentological investigation of the $\mathrm{Xi}$ amaling Formation at the Xiahuayuan section [6,30,33-35], a stratigraphic division scheme of six lithologic units in descending order was suggested. Among these, a $45 \mathrm{~m}$-thickness iron-rich sediment at the Xiahuayuan section is defined as unit 5, which can be further divided to the lower part with grayish-black mudstone and the upper part with green sandy mudstone [6,36] (Figure 1d). The mainly Fe-bearing mineral in unit 5 is siderite with layer or nodule characteristics [6]. These iron-rich layers or nodules have also been found in other outcrop sections of the Xiamaling Formation (Figure 1c) [7,28,31,37], indicating a large-scale iron deposition event [6]. However, due to weathering, the Xiamaling IF in the outcrop are mostly red or yellowish-brown (Figure 2a-d). Fresh siderite samples can only be seen in the core (Figure 2e,f). 

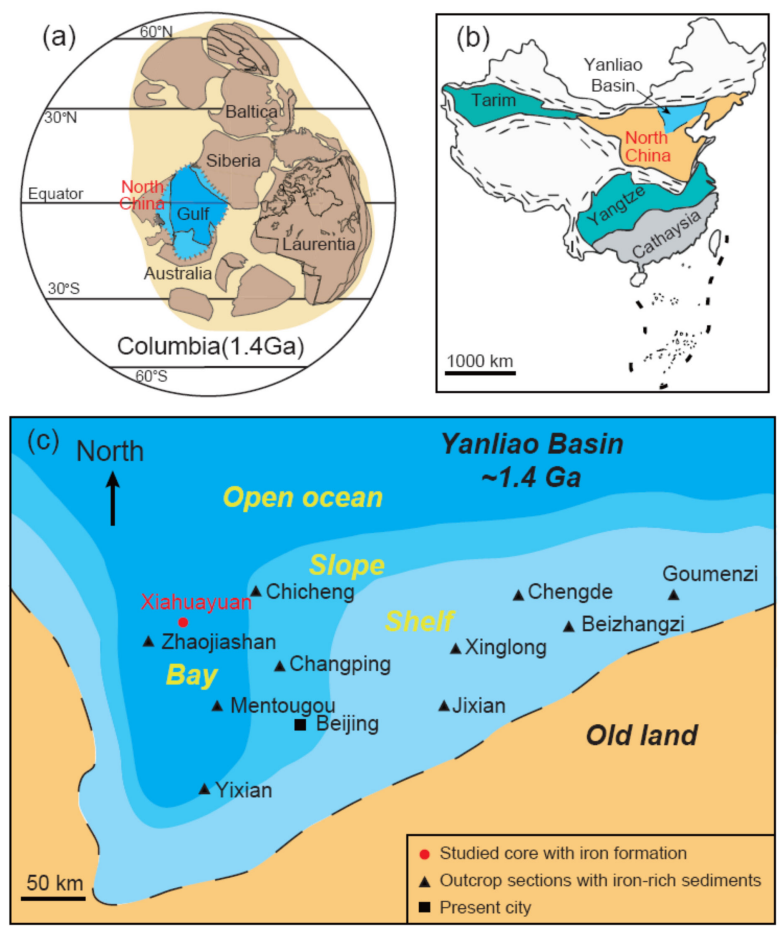

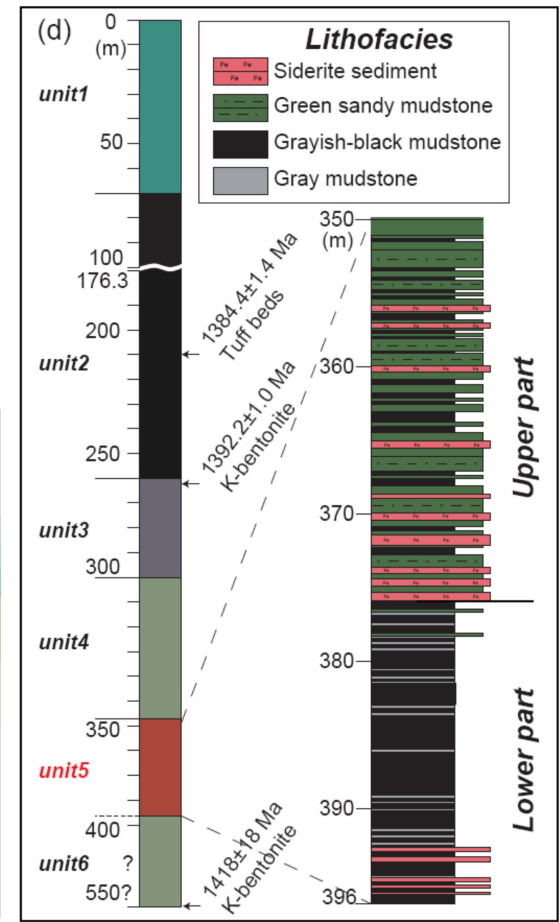

Figure 1. Location of the North China Craton at 1.4 Ga (a) and present (b). (c) Paleogeography of the Yanliao Basin at 1.4 Ga. (d) Stratigraphy of the Xiamaling iron formation defined as unit 5.
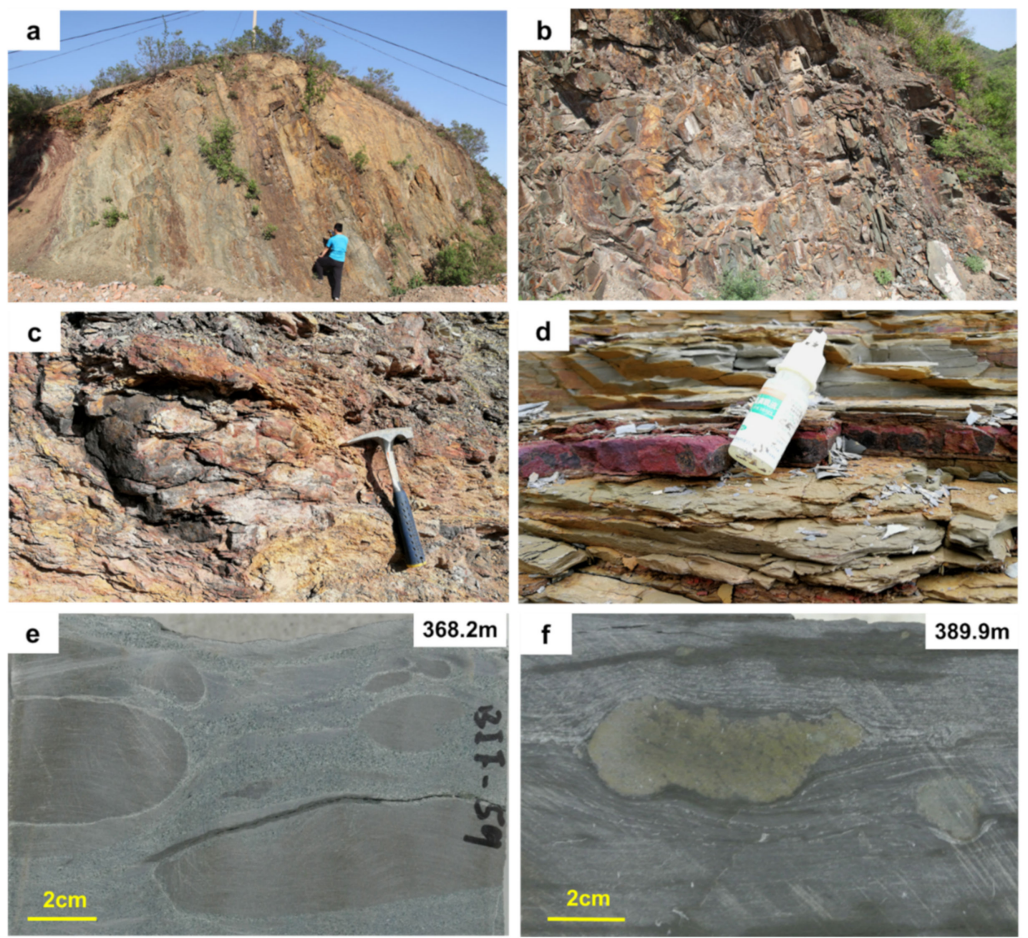

Figure 2. Photographs of the Xiamaling iron formation at the Xiahuayuan (a) and Zhaojiashan (b) sections. Photographs of the weathered siderite nodule (c) and layer (d) at the Xiahuayuan section. Photographs of the siderite nodules in the sandy mudstone (e) and gray shale (f). 


\section{Materials and Methods}

\subsection{Sample Preparation}

All samples in this study were collected from the Xiahuayuan section ( $40^{\circ} 28^{\prime} 13.41^{\prime \prime}$, E $115^{\circ} 15^{\prime} 52.9^{\prime \prime}$ ) of the Xiamaling Formation. In a 2.5-m-interval (from 393.75 to $395.90 \mathrm{~m}$ ) of a drilling core, five siderite samples and three shale samples were collected. Each siderite sample was crushed into 200-mesh powder using a tungsten carbide crushing vessel to do element analysis and inorganic carbon isotope $\left(\delta^{13} \mathrm{C}_{\text {carb }}\right)$ analysis. Each shale sample was divided into two parts to make a $30-\mu \mathrm{m}$-thick thin section and 200-mesh powder, respectively. The thin section was used to search the siderite crystal and to do element scanning by using LA-ICP-MS, while the powder was used to do element analysis and organic carbon isotope $\left({ }^{13} \mathrm{C}_{\mathrm{org}}\right)$ analysis. As a comparison, one siderite and one shale sample were also collected from the outcrop to make $30-\mu \mathrm{m}$-thick thin sections.

\subsection{Element Analyses}

Major and trace elements analyses were measured at the Beijing Research Institute of Uranium Geology, after the methods described in previous work [6]. Briefly, the major element analysis was performed using a Philips PW2400 X-ray fluorescence spectrometer (XRF, PANalytic Inc., Almelo, Netherlands), and the trace element analysis was performed using an ELEMENT XR inductively coupled plasma mass spectrometer (ICP-MS, Thermo Fisher Scientific Inc., Waltham, MA, USA). The relative standard deviations (RSD) of interest major and trace elements were lower than 3.0\%. Accuracies were tested with the shale standard (GBW 03014) that was measured along with the samples.

\subsection{Carbon Isotope Analyses}

$\delta^{13} \mathrm{C}_{\text {carb }}$ of siderites and $\delta^{13} \mathrm{C}_{\text {org }}$ of shales were measured at the University of Southern Denmark and Research Institute of Petroleum Exploration and Development (RIPED), respectively, after the methods described in previous work [6]. Briefly, the $\delta^{13} \mathrm{C}_{\text {carb }}$ of each sample was measured by reacting with phosphoric acid in an online carbonate preparation device and determining on a Finnigan Mat-252 mass spectrometer (Thermo Scientific Inc., Waltham, MA, USA). Pure kerogen was extracted from rocks through $\mathrm{HCl}$ and $\mathrm{HF}$ treatment as fully described in previous work [35]. The $\delta^{13} \mathrm{C}_{\text {org }}$ values were measured on the extracted kerogens by using a Flush EA 1112 HT O/H-N/C (Thermo Scientific Inc., Waltham, MA, USA) combined with a Delta V Advantage mass spectrometer (Thermo Fisher Scientific Inc., Waltham, MA, USA). All $\delta 13 C$ values were reported relative to the Vienna Pee Dee Belemnite (VPDB), with standard deviation (SD) of each sample being lower than $0.2 \%$ based on replicate analysis.

\subsection{Multi-Element Imaging Analysis}

Thin sections were observed using an Olympus BX51-P polarized light microscope. (Olympus Corp., Tokyo, Japan). The selected siderite crystal was marked to do multielement analysis using an Analyte Excite 193 nm LA system (Photon Machines Inc., Bozeman, MO, USA) and an iCAP-Q ICP-MS (Thermo Fisher Scientific Inc., Waltham, MA, USA). This experiment was carried out at the RIPED, after the method described in previous work [38-40]. Briefly, the scanning mode of LA was "line scan", while ICP-MS selected the "time resolved" with peak jumping mode. The parameters of LA system and ICP-MS were optimized using continuous ablation of a NIST 612 standard material to provide maximum sensitivity of interest elements, while maintaining low oxide formation $\left.{ }^{232} \mathrm{Th}^{16} \mathrm{O}^{+} /{ }^{232} \mathrm{Th}^{+}<0.5 \%\right)$. It was confirmed that, the time required to remove the light spot from the end of one line to the beginning of next line was about $0.5 \mathrm{~s}$, and the time required to reduce the signal counts from $>300,000$ to blank $(<0.1 \%$ maximum signal counts) in HelExII sample cell with He was about $2 \mathrm{~s}$, and the time required to transfer the aerosol particles from the sample cell of LA to ICP-MS and then to achieve the element signal counts was about $2 \mathrm{~s}$. Therefore, a pause of $5 \mathrm{~s}$ was set after each line ablation. Furthermore, it was necessary to match the pulse frequency of LA with the data acquisition 
frequency of ICP-MS to guarantee the complete recording of the ablated signal without cross-contamination [38]. Detailed instrument conditions and operating parameters are shown in Table 1.

Table 1. Measurement parameters of laser ablation inductively coupled plasma mass spectrometry instrument.

\begin{tabular}{cccc}
\hline \multicolumn{2}{c}{ Laser Ablation System (LA) } & Inductively Coupled Plasma Mass Spectrometry (ICP-MS) \\
\hline Wavelength & $193 \mathrm{~nm}$ & RF power & $1375 \mathrm{~W}$ \\
Pulse frequency & $5 \mathrm{~Hz}$ & Carrier gas (He) & $1.0 \mathrm{~L} / \mathrm{min}$ \\
Pulse energy & $5 \mathrm{~mJ}$ & Auxiliary gas (Ar) & $0.8 \mathrm{~L} / \mathrm{min}$ \\
Output of energy & $50 \%$ & Nebulizer gas (Ar) & $0.9 \mathrm{~L} / \mathrm{min}$ \\
Energy density & $7 \mathrm{~J} / \mathrm{cm}^{2}$ & Cool gas (Ar) & $14.0 \mathrm{~L} / \mathrm{min}$ \\
Spot size & $20 \mu \mathrm{m}$ & Dwell time & $5 \mathrm{~ms}$ \\
Scanning speed & $30 \mu \mathrm{m} / \mathrm{s}$ & Quadruple settling time & $2 \mathrm{~ms}$ \\
Scanning mode & Cine & CCT mode & Standard \\
Ablation line spacing & $5 \mu \mathrm{m}$ & Data acquisition & Time resolved \\
Pause time & $5 \mathrm{~s}$ & Elements & $\mathrm{Al}, \mathrm{Si}, \mathrm{Mn}, \mathrm{Fe}, \mathrm{Zn}$ \\
\hline
\end{tabular}

The matrix of NIST standard differs from that of the siderite, which can lead to a large impact on the LA efficiency. Moreover, some of the interest elements present in the NIST standard are in low contents and therefore are not suitable for quantitative calibration. Thus, we selected the surrounding rock to do quantitative calibration. With the assumption of selected ablation area of surrounding rock have equivalent element contents with the shale powder, which were precisely determined using XRF and ICPMS, respectively, the quantitative process of the LA-ICP-MS signals can be implemented according to the following equation:

$$
\mathrm{C}_{i}=\mathrm{S}_{i} / \mathrm{S}_{b i} \times \mathrm{C}_{b i}
$$

where $i$ is the interest element, $\mathrm{C}_{i}$ and $\mathrm{S}_{i}$ are the contents (with the unit of ppm or \%) and LAICP-MS signals (with the unit of cps) of element $i$ in each laser ablated point, respectively, $\mathrm{C}_{b i}$ is the average contents (with the unit of ppm or \%) of element $i$ in the surrounding rock as determined via XRF or ICP-MS, $\mathrm{S}_{b i}$ is the average LA-ICP-MS signal (with the unit of cps) of element $i$ in the surrounding rock.

\section{Results}

\subsection{Petrographic Characteristics of Siderite Crystals}

Petrographic analysis reveals that most siderite crystals are subhedral to euhedral with a generally brown core and bright rims (Figure 3a,b). Most siderite crystals show high-grade white interference color. In this study, siderite is primarily present as two types. In one type, the samples are almost entirely composed of siderite minerals, which are $~ 50$ $\mu \mathrm{m}$ subhedral (spherical) and densely packed (Figure 3a). In another, siderite crystals are discretely distributed in shale matrix (Figure $3 b$ ). This type of siderite is generally larger $(\sim 200 \mu \mathrm{m})$. In some well-preserved samples, euhedral rhombic crystals could be recognized (Figure $3 b, c)$.

However, for outcrop samples, due to surface weathering, siderite has been transformed into iron-oxides, such as limonite or goethite. These minerals are opaque under transmitted light. Though the boundaries between iron-rich minerals and matrix are still obvious (Figure 3d,e), those iron-bearing minerals have already lost their crystal characteristics (Figure 3e). 

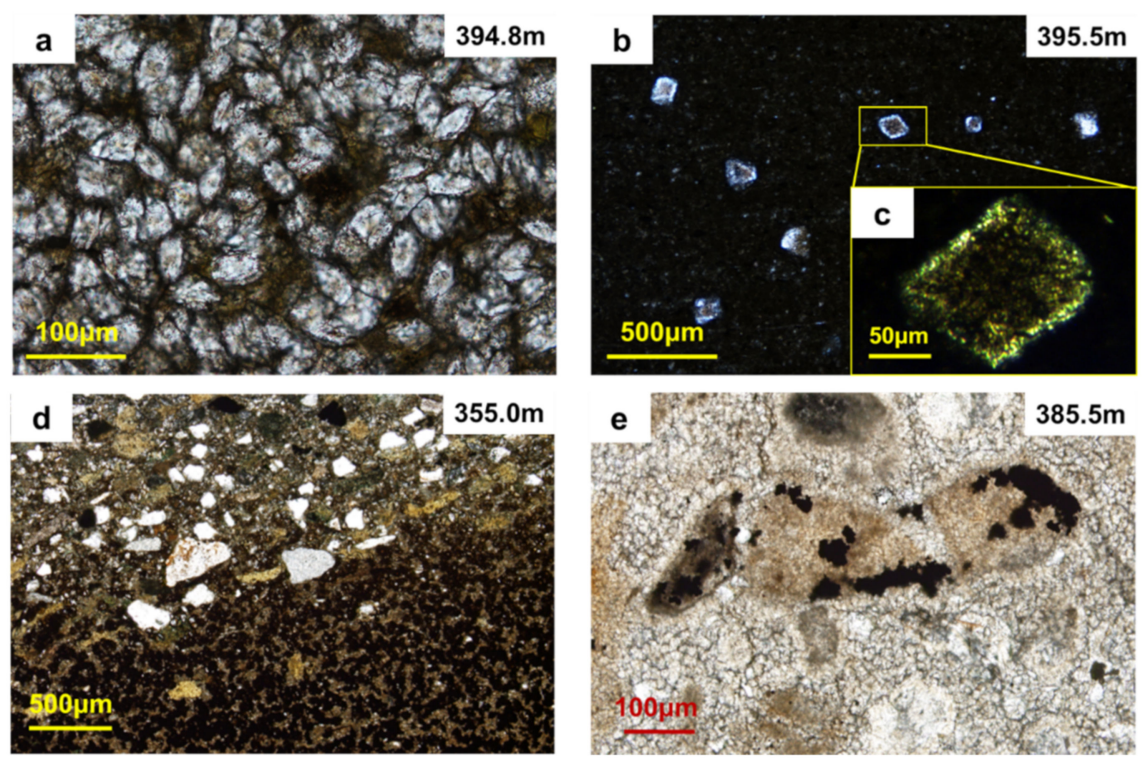

Figure 3. Photographs of the siderite crystals from the thin-sections of the pure siderite (a) and shale (b) samples from the Xiamaling Formation. (c) Photographs of an autogenic rhombohedral siderite. Photographs of the weathered iron (black spot) from the thin-sections (d,e) from outcrop.

\subsection{Geochemical Values of the Siderites and Shales}

The Fe contents of siderite samples range from $29.7 \%$ to $40.6 \%$, with an average value of $36.2 \%$, while the Fe contents of shale samples range from $3.7 \%$ to $4.5 \%$, with an average value of $4.1 \%$. Manganese is also enriched in the siderite samples. However, other elements that we concerned have higher contents in the shale samples (Table 2).

Table 2. Geochemical data of the Xiamaling siderites and shales. "/" denotes no data. Eu/Eu * $=2 \times \mathrm{EuN} /(\mathrm{SmN}+\mathrm{GdN})$, where the EuN, SmN and GdN are the normalized values of Eu, Sm and Gd with North American Shale Composite.

\begin{tabular}{|c|c|c|c|c|c|c|c|c|}
\hline Sample No. & $\begin{array}{l}\text { XML- } \\
393.75\end{array}$ & $\begin{array}{l}\text { XML- } \\
393.80\end{array}$ & $\begin{array}{l}\text { XML- } \\
394.70\end{array}$ & $\begin{array}{l}\text { XML- } \\
394.80\end{array}$ & $\begin{array}{l}\text { XML- } \\
395.15\end{array}$ & $\begin{array}{l}\text { XML- } \\
395.50\end{array}$ & $\begin{array}{l}\text { XML- } \\
395.65\end{array}$ & $\begin{array}{l}\text { XML- } \\
395.90\end{array}$ \\
\hline Lithology & siderite & shale & shale & siderite & siderite & shale & siderite & siderite \\
\hline$\delta^{13} C_{\text {org }}(\%$ o $)$ & / & -32.3 & -32.3 & / & / & -32.5 & / & / \\
\hline$\delta^{13} C_{c a r b}(\% o)$ & -11.9 & / & / & -13.2 & -12.5 & / & -15.4 & -13.2 \\
\hline $\mathrm{Si}(\%)$ & 12.1 & 29.1 & 28.7 & 8.1 & 4.2 & 28.8 & 3.9 & 6.6 \\
\hline $\mathrm{Al}(\%)$ & 2.89 & 9.96 & 9.64 & 1.20 & 0.40 & 9.78 & 0.43 & 1.80 \\
\hline $\mathrm{Fe}(\%)$ & 29.7 & 3.7 & 4.5 & 35.1 & 40.2 & 4.2 & 40.6 & 35.5 \\
\hline Mn (\%) & 0.64 & 0.01 & 0.02 & 0.54 & 0.71 & 0.01 & 0.54 & 0.65 \\
\hline $\mathrm{Zn}(\mathrm{ppm})$ & 80.1 & 60.9 & 89.8 & 58.1 & 48.3 & 87.5 & 56.9 & 55.1 \\
\hline $\mathrm{La}(\mathrm{ppm})$ & 10.2 & 35.9 & 36.5 & 4.26 & 2.25 & 40.9 & 2.68 & 8.67 \\
\hline $\mathrm{Ce}$ (ppm) & 21.1 & 70.4 & 71.5 & 9.68 & 5.62 & 79.1 & 7.56 & 17.4 \\
\hline $\operatorname{Pr}(\mathrm{ppm})$ & 2.58 & 8.40 & 8.39 & 1.31 & 0.87 & 9.28 & 1.14 & 2.30 \\
\hline Nd (ppm) & 10.1 & 32.0 & 32.1 & 5.49 & 3.23 & 35.9 & 5.29 & 9.54 \\
\hline Sm (ppm) & 2.37 & 5.8 & 5.96 & 1.43 & 1.11 & 6.73 & 2.03 & 2.59 \\
\hline $\mathrm{Eu}(\mathrm{ppm})$ & 0.59 & 1.09 & 1.09 & 0.38 & 0.27 & 1.25 & 0.54 & 0.57 \\
\hline Gd (ppm) & 2.54 & 5.03 & 5.10 & 1.73 & 1.4 & 5.69 & 2.74 & 3.24 \\
\hline $\mathrm{Tb}(\mathrm{ppm})$ & 0.51 & 0.87 & 0.87 & 0.33 & 0.26 & 0.96 & 0.44 & 0.57 \\
\hline Dy (ppm) & 2.90 & 4.73 & 4.51 & 1.85 & 1.41 & 5.02 & 2.10 & 3.05 \\
\hline Ho (ppm) & 0.61 & 0.99 & 0.91 & 0.34 & 0.25 & 1.02 & 0.36 & 0.57 \\
\hline $\operatorname{Er}(\mathrm{ppm})$ & 1.56 & 2.69 & 2.41 & 0.98 & 0.71 & 2.76 & 0.90 & 1.80 \\
\hline $\operatorname{Tm}(\mathrm{ppm})$ & 0.27 & 0.53 & 0.47 & 0.14 & 0.10 & 0.54 & 0.13 & 0.27 \\
\hline $\mathrm{Yb}(\mathrm{ppm})$ & 1.68 & 3.37 & 3.01 & 0.99 & 0.69 & 3.41 & 0.94 & 1.79 \\
\hline $\mathrm{Lu}(\mathrm{ppm})$ & 0.23 & 0.46 & 0.41 & 0.12 & 0.08 & 0.47 & 0.10 & 0.21 \\
\hline $\mathrm{Y}(\mathrm{ppm})$ & 16.4 & 26.0 & 24.3 & 9.07 & 7.46 & 27.3 & 10.6 & 17.7 \\
\hline $\mathrm{Eu} / \mathrm{Eu}^{*}$ & 1.22 & 1.01 & 0.99 & 1.23 & 1.11 & 1.01 & 1.15 & 0.99 \\
\hline
\end{tabular}

The $\delta^{13} \mathrm{C}_{\text {carb }}$ of five siderite samples ranges from $-15.4 \%$ to $-11.9 \%$, with an average value of $-13.2 \%$, while the shale samples have a rather stable $\delta^{13} \mathrm{C}_{\text {org }}$ of $-32.4 \%$ (Table 2 ). 


\subsection{Multi-Element Imaging of a Siderite Crystal}

Fe is the most abundant element in siderite with no obvious rim structure (Figure 4). The average Fe content of the crystal is $32.7 \%$, corresponding to a $\mathrm{FeCO}_{3}$ purity of $72.5 \%$. Compared with the surrounding shale, both $\mathrm{Mn}$ and $\mathrm{Zn}$ are enriched in the siderite with similar rim structures. From the core to edge, elements of $\mathrm{Mn}$ and $\mathrm{Zn}$ are synchronously enriched (rim 1), weakly enriched (rim 2), enriched (rim 3), and weakly enriched (rim 4) in turn (Figure 4). The wave features of the quantified contents of $\mathrm{Zn}$ and $\mathrm{Mn}$ in different rims varied over $50 \%$ between peaks and valleys (Figure 5).

(a)

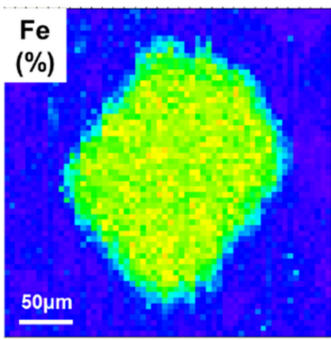

(d)

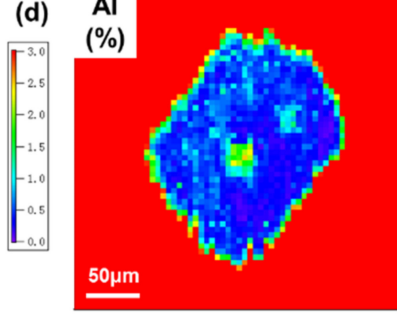

(b)

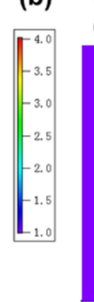

(e)

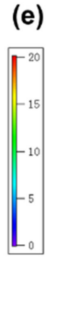

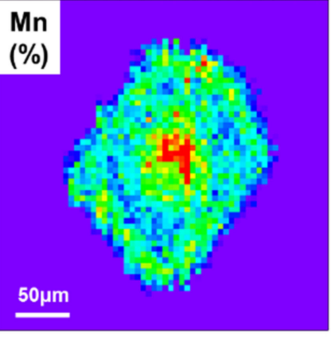

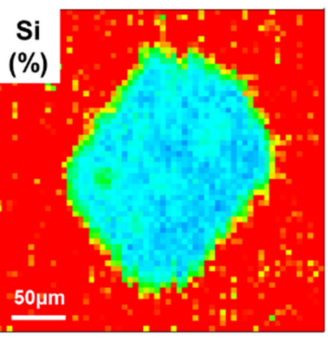

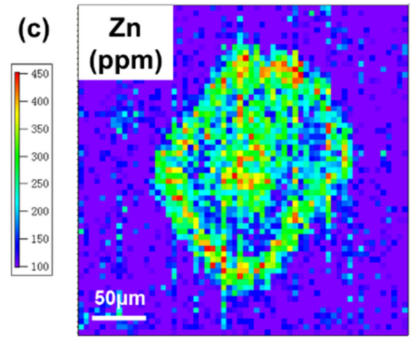

(f)

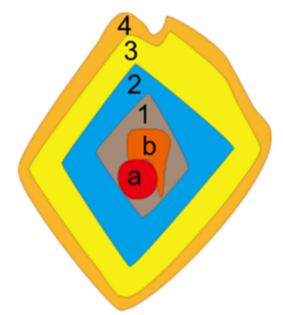

Figure 4. Multi-element imaging of an authigenic siderite crystal and its shale matrix obtained from the Laser ablation inductively coupled plasma mass spectrometry analysis. (a): Fe; (b): Mn; (c) Zn; (d): Al; (e): Si; (f) Structure diagram of the analyzed siderite crystal.

Contrary to $\mathrm{Mn}$ and $\mathrm{Zn}, \mathrm{Al}$ and $\mathrm{Si}$ exhibit depleted characteristics in the siderite crystal without obvious rims. However, in the core of crystal, there is a special zone (defined as zone a) with an $\mathrm{Al}$ content of $1.7 \%$, higher than that in rim $2(\sim 0.4 \%)$ and rim $3(\sim 0.6 \%)$ (Figure 5). Next to zone a, there is another special zone (defined as zone b) with a Mn content of 3.8\%, higher than that in rim $2(\sim 1.9 \%)$ and rim $3(\sim 2.5 \%)$. Thus, $\mathrm{Al}$ and $\mathrm{Mn}$ have further converse enrichment trends in zones a and $b$, while other elements do not show any differences (Figures 4 and 5). 

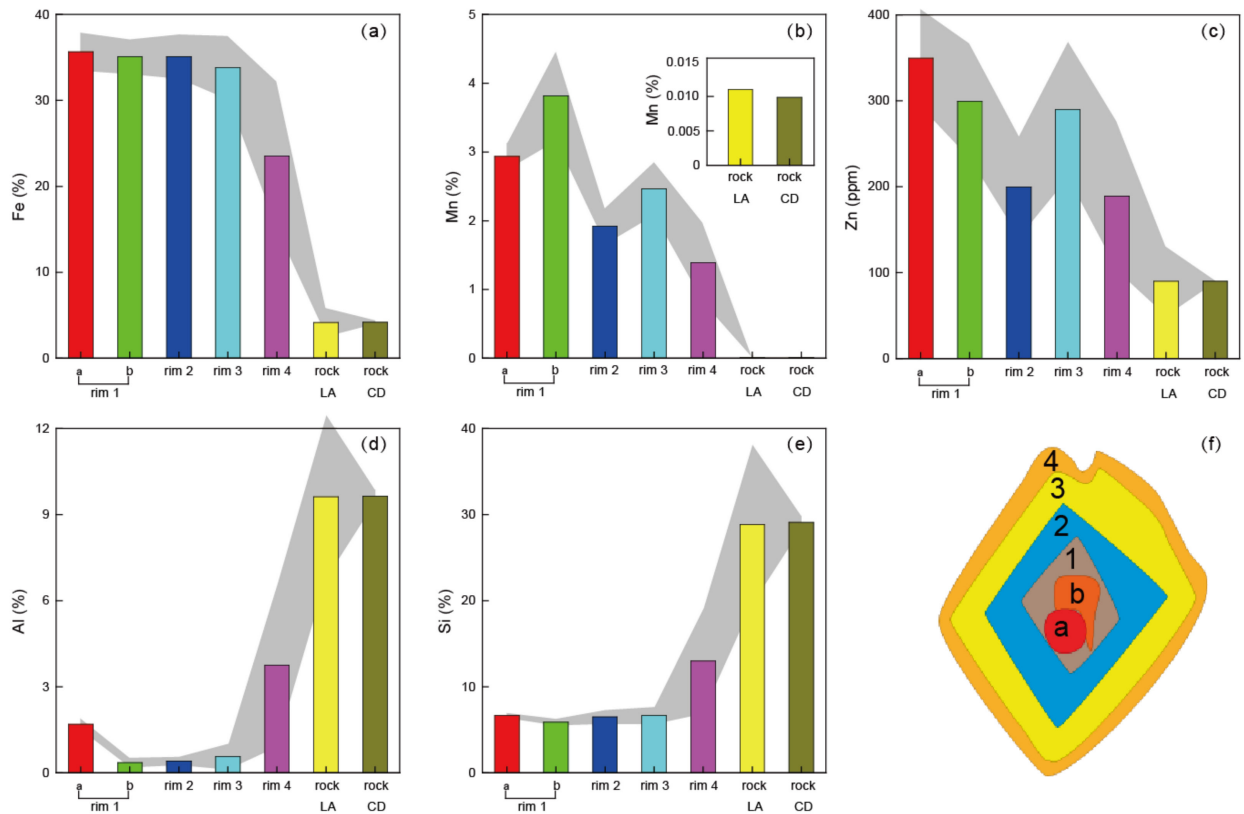

Figure 5. Element contents in different rims and zones, measured by LA-ICP-MS. Zones a and b are the rim 1 (core) of the crystal. The element contents in rock measured using chemical dissolution method (CD) were used to calculate the elements contents measured using LA-ICP-MS method (LA). The gray shadows indicate the standard division. (a): $\mathrm{Fe}$; (b): Mn; (c) $\mathrm{Zn} ;(\mathbf{d})$ : $\mathrm{Al}$; (e): Si; (f) Structure diagram of the analyzed siderite crystal.

\section{Discussion}

As an authigenic mineral, the crystal and growth of siderite in a water column or pore water generally need three conditions [21]. Firstly, a sufficient supply of $\mathrm{Fe}^{2+}$ and $\mathrm{HCO}_{3}{ }^{-}$to satisfy the requirement of crystallize and growth of the siderite. Secondly, a weakly alkaline and reducing water condition to ensure the $\mathrm{Fe}^{2+}$ and $\mathrm{HCO}_{3}{ }^{-}$at saturated-oversaturated concentrations. Thirdly, a nucleus to allow the crystallization products of $\mathrm{Fe}^{2+}$ and $\mathrm{HCO}_{3}{ }^{-}$ grow around.

\subsection{Supply of $\mathrm{Fe}^{2+}$ and $\mathrm{HCO}_{3}{ }^{-}$by Dissimilatory Iron Reduction}

Almost throughout the whole Mesoproterozoic Era, the deep ocean was dominated by ferruginous water [41], including the Yanliao Basin $1.4 \mathrm{Ga}[6,33,34,36,42]$. Hydrothermal fluid has also been considered to be active during the breakup of the Columbia supercontinent $[7,8]$. However, the $\mathrm{Eu} / \mathrm{Eu}^{*}$ of our siderite samples are from 1 to 1.2 (Table 1 ), located in the range of the previous reported Xiamaling IF (Eu/Eu* ratios 1-1.4) [6,7], but still much lower than that of the $1.33 \mathrm{Ga}$ Jingtieshan IF (Eu/Eu* ratios 4.4-6.5) [8] and the 3.8-1.8 Ga IFs (Eu/Eu* ratios 1.0-6.5) [1], suggesting an uncertain and possibly minor contribution of hydrothermal $\mathrm{Fe}^{2+}$.

Another possible external source of seawater $\mathrm{Fe}^{2+}$ would be from the benthic shuttle transport from shelf [43] or terrestrial input [44]. Considering the widely distributed Xiamaling IF covering the whole Yanliao Basin, the benthic shuttle transport is also an unlikely contributor. Therefore, the most possible source should be biologically recycled continental $\mathrm{Fe}$, which has been suggested as a major component in the $2.5 \mathrm{Ga}$ Dales Gorge member IF [45]. Considering the still low oxidation levels in Mesoproterozoic atmosphere and ocean $[46,47]$, the iron cycle in the ocean might be comparable to that of the terminal Archaean [36]. No matter which reason takes over, a ferruginous-dominated ocean during the Xiamaling Formation has already been confirmed $[6,33,34,36,42,48]$. Thus, $\mathrm{Fe}^{2+}$ would not be the limiting factor.

Experimental results have confirmed that $\mathrm{HCO}_{3}{ }^{-}$is a decisive factor in siderite formation [26]. Different from the underlying carbonate-rock-dominated Tieling Formation [49], 
carbonate rocks are quite rare in the clastic-rock-dominated Xiamaling Formation [30]. This great change indicates a major variation of the marine water conditions, at least in the Yanliao Basin, which might reduce the $\mathrm{HCO}_{3}{ }^{-}$concentration and end the deposition of carbonate rocks. An average $\delta^{13} \mathrm{C}_{\text {carb }}$ value of siderite samples from the lower part of the Xiamaling IF was $-13.2 \%$, much lower than that of the Mesoproterozoic seawater $\mathrm{HCO}_{3}{ }^{-}(\sim 0 \%)$ [50], but slightly heavier than the previous reported data (with an average value of $-16.0 \%$ ) from the upper part of the Xiamaling IF [6,7]. The formation of ${ }^{12} \mathrm{C}-$ depleted siderite was attributed to the contribution of organic-sourced $\mathrm{HCO}_{3}{ }^{-}$through dissimilatory iron reduction (DIR) [6,7]. Considering the average $\delta^{13} \mathrm{C}_{\text {org }}$ value of $-32.4 \%$ (Table 2) [6], the percentage of organic-sourced $\mathrm{HCO}_{3}{ }^{-}$in the lower part of Xiamaling IF was about $40 \%$. This is an important supplement to the $\mathrm{HCO}_{3}{ }^{-}$in a water column and pore water.

Since the Xiamaling siderites are mainly interbedded with shale or sandstone as layers or nodules, the capture of organic-sourced $\mathrm{HCO}_{3}{ }^{-}$by $\mathrm{Fe}^{2+}$ probably mainly occurred in pore water. Therefore, the siderite should be formed in a semi-closed to closed pore water conditions with $\mathrm{Fe}^{2+}$ and $\mathrm{HCO}_{3}{ }^{-}$supplies from seawater through DIR. A relatively closed pore water condition could also prevent the combination of $\mathrm{HCO}_{3}{ }^{-}$with $\mathrm{Ca}^{2+}$ to form calcite crystals, which, nevertheless, has a higher growth rate than siderite [19]. During the deposition period of the Xiamaling IF, DIR might have been quite vigorous, and could have reduced almost all the sinking iron-oxides into $\mathrm{Fe}^{2+}$ to form siderite later $[6,7,36]$.

\subsection{Weakly Alkaline and Manganese-Ferruginous Pore Water}

Increased $\mathrm{HCO}_{3}{ }^{-}$concentration in the pore water can lead to weakly alkaline water condition. However, the generation of weakly reducing water is related to the participation of multiple elements. DIR and sulfate reduction will consume the Fe-oxides and sulfate in the water column and pore water and generate $\mathrm{Fe}^{2+}$ and $\mathrm{HS}^{-}$, respectively [51]. The generated $\mathrm{HS}^{-}$can combine with $\mathrm{Fe}^{2+}$; then form pyrite $\left(\mathrm{FeS}_{2}\right)$. In the thin sections, we did not find pyrite in neither siderite nor shale samples. Previous studies also suggested ferruginous water for the lack of pyrite and rich in siderite $[6,7,36]$.

Here, our multi-element imaging result provides new evidence of the weakly reducing water conditions. Although there is no significant difference in the distribution of Fe on the crystal, four rhombic rims can still be recognized through the distributions of $\mathrm{Mn}$ and $\mathrm{Zn}$ (Figure 4). Firstly, enriched $\mathrm{Mn}$ in the core of crystal indicates the reduction of Mn-oxides and Fe-Mn-oxyhydroxides to $\mathrm{Mn}^{2+}$ [51]. $\mathrm{Zn}^{2+}$ is mostly present as complexes with humic/fulvic acids or adsorbed onto particulate Fe-Mn-oxyhydroxides [52]. Therefore, it can be released from the oxidation of organic matter and the reduction of Fe-Mn-oxyhydroxides. Because $\mathrm{Zn}^{2+}$ and $\mathrm{Mn}^{2+}$ are prone to form rhodochrosite and magnesite in the weakly alkaline, metallogenic environment, the released $\mathrm{Mn}^{2+}$ and $\mathrm{Zn}^{2+}$ could combine with $\mathrm{HCO}_{3}{ }^{-}$and form the first enrichment rim in the siderite crystal. Thus, the siderite might begin crystallization in manganese water, and grow in ferruginous water.

However, since minor changes in the $\mathrm{Eh}$ and $\mathrm{pH}$ of the medium lead to great changes in sedimentary $\mathrm{Mn} / \mathrm{Fe}$ ratios [53], the rims of $\mathrm{Mn}$ in the siderite might indicate subtle varying water conditions during the crystal growth, which is different from the modern ferruginous lakes [21].

\subsection{Fe-Bearing Mineral as a Nucleus}

When the first two conditions have been met, the third requirement for siderite crystallization is a suitable nucleus, which can be a clastic particle (e.g., hematite, quartz, and feldspar) or even an organism remnant [21]. For our imaging sample, zone a in rim 1 with higher $\mathrm{Al}$ content might be the nucleus. Because Al mainly exists in clay minerals, it can only exist before the siderite crystallization, and cannot be brought in during the crystallization process. However, this nucleus has an Fe content $(\sim 36 \%)$ similar to siderite, which can be determined to be an iron-bearing mineral. Robust DIR can almost 
completely reduce the hematite that has a much higher Fe content (70\%) than siderite. This nucleus does not show any enrichment of $\mathrm{Si}$, so the possibility of ferric silicate can also be ruled out. Therefore, it is most likely to be a residual siderite crystal with some clay contamination.

In fact, the occurrence of residual siderite crystal in 1.4 Ga sediments should be common. Firstly, the already found $\sim 1.45 \mathrm{Ga}$ Sherwin Ironstone in North Australia [10] and $1.33 \mathrm{Ga}$ Jingtieshan IF in Qilian [8] are siderite-dominated IF. Manganiferous dolostones are also present in the Tieling Formation $(\sim 1.44 \mathrm{Ga})$ and Gaoyuzhuang Formation $(\sim 1.58 \mathrm{Ga})$ [54-56]. These findings indicate that massive Fe and Mn deposits still existed in the Mesoproterozoic oceans but mainly in the form of carbonates. Secondly, there is a large unconformity between the Xiamaling and Tieling formations, indicating robust weathering and erosion of early sediments [31]. In different outcrop section, almost all the weathering crusts at the bottom of the Xiamaling Formation have high Fe contents [31,57]. The clastic materials such as sandstones and mudstones deposited above the crust are also rich in Fe [31,57]. Thus, it is possible that previously deposited carbonate minerals were uplifted to the surface by regional tectonic movement, and entered into the ocean again. The siderite nuclei found in this study provide mineral inclusion evidence for a possible siderite oxidation event at $1.4 \mathrm{Ga}$.

\subsection{Growth of the Siderite Crystal}

Different from the crystals in the siderite sample with a size around $50 \mu \mathrm{m}$, the siderite crystal in the shale sample can grow to $200 \mu \mathrm{m}$ (Figure 4). Euhedral rhombohedral characteristic of the scanned siderite further indicates a weakly alkaline and closed water condition, which thereby allows the siderite to slowly grow as euhedral crystals [58]. However, unlike the uniform distribution of Fe on the crystal surface, the depletion of Mn and $\mathrm{Zn}$ in rim 2 might be caused by the failure to replenish them in a timely manner as the ions were deposited in a closed environment. In rim 3, the re-enriched Mn and $\mathrm{Zn}$ might be from the ferruginous pore water, which had limited $\mathrm{Zn}^{2+}$ and $\mathrm{Mn}^{2+}$. Then, the contents of $\mathrm{Mn}, \mathrm{Zn}$, and Fe underwent sharp decreases, while $\mathrm{Al}$ and $\mathrm{Si}$ contents increased conversely (Figures 4 and 5), indicating a relatively open pore water with more clay and silicate minerals. In sum, the rim in this crystal should be an indicator for the varied pore water conditions which changed from closed into semi-closed (Figure 6).

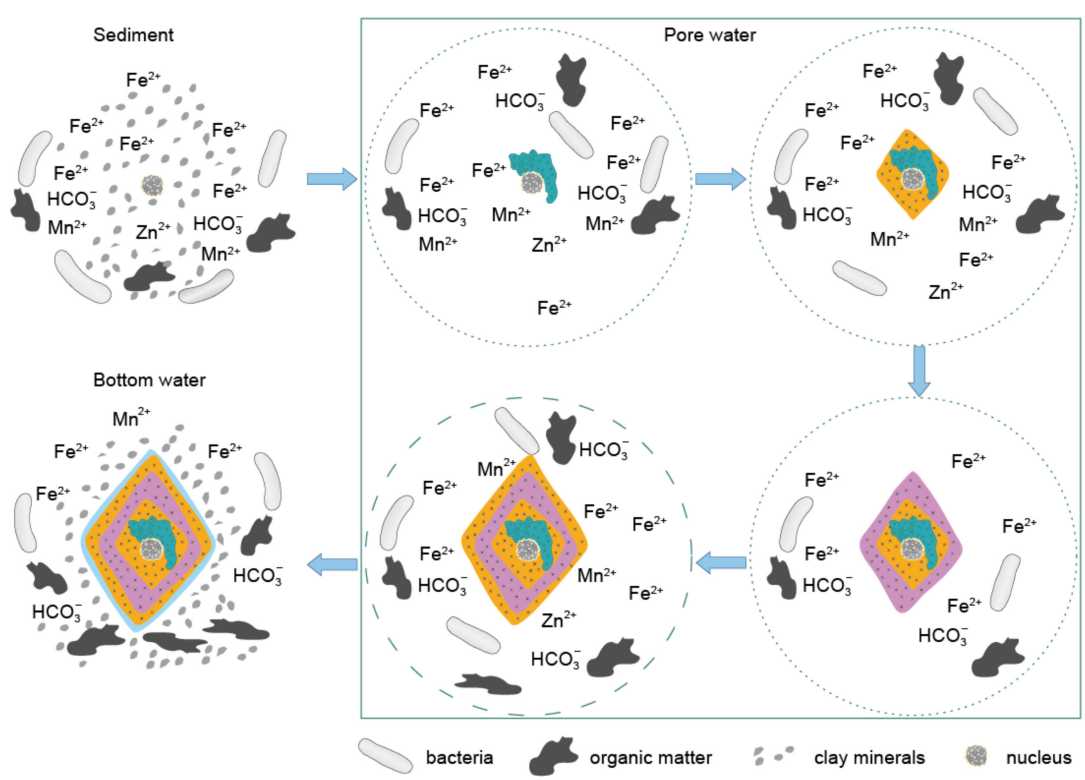

Figure 6. Conceptual model illustrating the crystallization and grow process of the studied siderite from the Xiamaling iron formation. The dot and dash circle in the pore water square represent closed and semi-closed condition, respectively. 


\section{Conclusions}

In-situ multi-element imaging of an authigenic siderite crystal provides novel evidence for us to understand the crystallization process of the Xiamaling IF. Although we have no conclusive evidence to prove the crystal nucleus as siderite, the occurrence of Febearing nucleus still confirm the input of terrestrial weathered Fe to the ocean. This should be an important effect on the Fe cycle in ocean, especially the Yanliao Basin far away from the hydrothermal vents. Combined with the negative carbon isotope values of the Xiamaling siderite, vigorous dissimilatory iron reduction is suggested as a key role to form the siderite-dominated iron formation. Furthermore, the iron cycle in the surface ocean water of early earth could have an intimate relationship with the carbon cycle and Earth oxygenation, which requires further investigation.

Author Contributions: Conceptualization, H.W. and Y.Y.; methodology, H.W. and Y.Y.; investigation, H.W., Y.Y., Y.D., F.Z.; resources, H.W., Y.Y., X.W. and S.Z.; data curation, H.W. and Y.Y.; writingoriginal draft preparation, H.W. and Y.Y.; writing-review and editing, H.W., Y.Y., Y.L. (Yuke Liu) and Y.L. (Yitong Lyu); supervision, H.W. and S.Z.; project administration, H.W. and S.Z.; funding acquisition, H.W. All authors have read and agreed to the published version of the manuscript.

Funding: This research was funded by the Strategic Priority Research Program of the Chinese Academy of Sciences, grant number XDA14010101, the National Key Research and Development Program of China, grant number 2017YFC0603101, and the National Natural Science Foundation of China, grant number 41872125 .

Acknowledgments: We sincerely thank the five anonymous reviewers for their comments, which are of great significance to improve the quality of this paper.

Conflicts of Interest: The authors declare no conflict of interest.

\section{References}

1. Konhauser, K.O.; Planavsky, N.J.; Hardisty, D.S.; Robbins, L.J.; Warchola, T.J.; Haugaard, R.; Lalonde, S.V.; Partin, C.A.; Oonk, P.B.H.; Tsikos, H.; et al. Iron formations: A global record of Neoarchaean to Palaeoproterozoic environmental history. Earth-Sci. Rev. 2017, 172, 140-177. [CrossRef]

2. Holland, H.D. Origins of breathable air. Nature 1990, 347, 17. [CrossRef]

3. Canfield, D.E. A new model for Proterozoic ocean chemistry. Nature 1998, 396, 450-453. [CrossRef]

4. Canfield, D.E.; Poulton, S.W.; Knoll, A.H.; Narbonne, G.M.; Ross, G.; Goldberg, T.; Strauss, H. Ferruginous conditions dominated later neoproterozoic deep-water chemistry. Science 2008, 321, 949-952. [CrossRef] [PubMed]

5. Poulton, S.W.; Canfield, D.E. Ferruginous conditions: A dominant feature of the ocean through earth's history. Elements 2011, 7, 107-112. [CrossRef]

6. Canfield, D.E.; Zhang, S.C.; Wang, H.J.; Wang, X.M.; Zhao, W.Z.; Su, J.; Bjerrum, C.; Haxen, E.; Hammarlund, E. A Mesoproterozoic Iron Formation. Proc. Nat. Acad. Sci. USA 2018, 115, E3895-E3904. [CrossRef]

7. Tang, D.J.; Shi, X.Y.; Jiang, G.Q.; Wu, T.; Ma, J.B.; Zhou, X.Q. Stratiform siderites from the Mesoproterozoic Xiamaling Formation in North China: Genesis and environmental implications. Gondwana Res. 2018, 58, 1-15. [CrossRef]

8. Yang, X.Q.; Zhang, Z.H.; Santosh, M.; Duan, S.G.; Liang, T. Anoxic to suboxic Mesoproterozoic ocean: Evidence from iron isotope and geochemistry of siderite in the Banded Iron Formations from North Qilian, NW China. Precambrian Res. 2018, 307, 115-124. [CrossRef]

9. Bekker, A.; Slack, J.F.; Planavsky, N.; Krapež, B.; Hofmann, A.; Konhauser, K.O.; Rouxel, O.J. Iron formation: The sedimentary product of a complex interplay among mantle, tectonic, oceanic, and biospheric processes. Econ. Geol. 2010, 105, 467-508. [CrossRef]

10. Planavsky, N.J.; Reinhard, C.T.; Wang, X.L.; Thomson, D.; McGoldrick, P.; Rainbird, R.H.; Johnson, T.; Fischer, W.W.; Lyons, T.W. Low Mid-Proterozoic atmospheric oxygen levels and the delayed rise of animals. Science 2014, 346, 635-638. [CrossRef]

11. Czaja, A.D.; Johnson, C.M.; Beard, B.L.; Eigenbrode, J.L.; Freeman, K.H.; Yamaguchi, K.E. Iron and carbon isotope evidence for ecosystem and environmental diversity in the $\sim 2.7$ to 2.5 Ga Hamersley Province, Western Australia. Earth Planet. Sci. Lett. 2010, 292, 170-180. [CrossRef]

12. Mulders, J.J.; Tobler, D.J.; Oelkers, E.H. Siderite nucleation pathways as a function of aqueous solution saturation state at $25^{\circ} \mathrm{C}$. Chem. Geol. 2021, 559, 119947. [CrossRef]

13. Effenberger, H.; Mereiter, K.; Zemann, J. Crystal structure refinements of magnesite, calcite, rhodochrosite, siderite, smithonite, and dolomite, with discussion of some aspects of the stereochemistry of calcite type carbonates. Z. Krist. -Cryst. Mater. 1981, 156, 233-244. [CrossRef]

14. Wagner, T.; Cook, N. Sphalerite remobilization during multistage hydrothermal mineralization events-examples from siderite$\mathrm{Pb}-\mathrm{Zn}-\mathrm{Cu}-\mathrm{Sb}$ veins, Rheinisches Schiefergebirge, Germany. Miner. Petrol. 1998, 63, 223-241. [CrossRef] 
15. Burisch, M.; Walter, B.F.; Gerdes, A.; Lanz, M.; Markl, G. Late-stage anhydrite-gypsum-siderite-dolomite-calcite assemblages record the transition from a deep to a shallow hydrothermal system in the Schwarzwald mining district, SW Germany. Geochim. Cosmochim. Acta 2018, 223, 259-278. [CrossRef]

16. Ellmies, R.; Voigtländer, G.; Germann, K.; Krupenin, M.; Moeller, P. Origin of giant stratabound deposits of magnesite and siderite in Riphean carbonate rocks of the Bashkir mega-anticline, western Urals. Geol. Rundsch. 1999, 87, 589-602.

17. Heimann, A.; Johnson, C.M.; Beard, B.L.; Valley, J.W.; Roden, E.E.; Spicuzza, M.J.; Beukes, N.J. Fe, C, and O isotope compositions of banded iron formation carbonates demonstrate a major role for dissimilatory iron reduction in 2.5 Ga marine environments. Earth Planet. Sci. Lett. 2010, 294, 8-18. [CrossRef]

18. Li, Y.; Huang, W.; Jiu, B.; Sun, Q.; Che, Q. Modes of occurrence and origin of minerals in Permian coals from the Huainan coalfield, Anhui, China. Minerals 2020, 10, 399. [CrossRef]

19. Jiang, C.Z.; Tosca, N.J. Growth kinetics of siderite at $298.15 \mathrm{~K}$ and 1 bar. Geochim. Cosmochim. Acta 2020, 274, 97-117. [CrossRef]

20. Mozley, P.S. Relation between depositional environment and the elemental composition of early diagenetic siderite. Geology 1989, 17, 704-706. [CrossRef]

21. Vuillemin, A.; Wirth, R.; Kemnitz, H.; Schleicher, A.M.; Friese, A.; Bauer, K.W.; Simister, R.; Nomosatryo, S.; Ordoñez, L.; Ariztegui, D. Formation of diagenetic siderite in modern ferruginous sediments. Geology 2019, 47, 540-544. [CrossRef]

22. Köhler, I.; Konhauser, K.O.; Papineau, D.; Bekker, A.; Kappler, A. Biological carbon precursor to diagenetic siderite with spherical structures in iron formations. Nat. Commun. 2013, 4, 1741. [CrossRef] [PubMed]

23. Kamran, A.; Schneider, D.; Roddatis, V.; Thiel, V.; Hoppert, M. Formation of siderite in microbial microcosms derived from a marine sediment. Geomicrobio. J. 2020, 37, 475-485. [CrossRef]

24. Sengupta, R.; Tosca, N.J.; Robinson, S.A. Geochemical controls on the elemental composition of siderite: Implications for palaeo-environmental reconstructions. Geochim. Cosmochim. Acta 2020, 271, 1-15. [CrossRef]

25. Pe-Piper, G.; Piper, D.J. Significance of the chemistry and morphology of diagenetic siderite in clastic rocks of the Mesozoic Scotian Basin. Sedimentology 2020, 67, 782-809. [CrossRef]

26. Koo, T.-h.; Kim, J. Controls on the formation and stability of Siderite $\left(\mathrm{FeCO}_{3}\right)$ and Chukanovite $\left(\mathrm{Fe}_{2}(\mathrm{CO} 3)(\mathrm{OH})_{2}\right)$ in reducing environment. Minerals 2020, 10, 156. [CrossRef]

27. Yang, X.Q.; Zhang, Z.H.; Duan, S.G.; Zhao, X.M. Petrological and geochemical features of the Jingtieshan banded iron formation (BIF): A unique type of BIF from the Northern Qilian Orogenic Belt, NW China. J. Asian Earth Sci. 2015, 113, 1218-1234. [CrossRef]

28. Zhang, K.; Zhu, X.K. Basic geological characteristics of the siderite-rich strata in the Xiamaling Formation, Jixian County. Acta Petrol. Miner. 2013, 32, 529-537. (In Chinese)

29. Meng, Q.R.; Wei, H.H.; Qu, Y.Q.; Ma, S.X. Stratigraphic and sedimentary records of the rift to drift evolution of the northern North China craton at the Paleo-to Mesoproterozoic transition. Gondwana Res. 2011, 20, 205-218. [CrossRef]

30. Zhang, S.C.; Wang, X.M.; Hammarlund, E.U.; Wang, H.J.; Costa, M.M.; Bjerrum, C.J.; Connelly, J.N.; Zhang, B.M.; Bian, L.Z.; Canfield, D.E. Orbital forcing of climate 1.4 billion years ago. Proc. Nat. Acad. Sci. USA 2015, 112, E1406-E1413. [CrossRef]

31. Lyu, D.; Deng, Y.; Wang, H.; Zhang, F.; Ren, R.; Gao, Z.; Zhou, C.; Luo, Z.; Wang, X.; Bi, L.; et al. Using cyclostratigraphic evidence to define the unconformity caused by the Mesoproterozoic Qinyu Uplift in the North China Craton. J. Asian Earth Sci. 2021, 206, 104608. [CrossRef]

32. Zhang, S.H.; Zhao, Y.; Li, X.H.; Ernst, R.E.; Yang, Z.Y. The 1.33-1.30 Ga Yanliao large igneous province in the North China Craton: Implications for reconstruction of the Nuna (Columbia) supercontinent, and specifically with the North Australian Craton. Earth Planet. Sci. Lett. 2017, 465, 112-125. [CrossRef]

33. Zhang, S.C.; Wang, X.M.; Wang, H.J.; Bjerrum, C.J.; Hammarlund, E.U.; Haxen, E.R.; Wen, H.J.; Ye, Y.T.; Canfield, D.E. Paleoenvironmental proxies and what the Xiamaling Formation tells us about the mid-Proterozoic ocean. Geobiology 2019, 17, 225-246. [CrossRef]

34. Wang, X.M.; Zhang, S.C.; Wang, H.J.; Bjerrum, C.J.; Hammarlund, E.U.; Haxen, E.R.; Su, J.; Wang, Y.; Canfield, D.E. Oxygen, climate and the chemical evolution of a 1400-million-year old tropical marine setting. Am. J. Sci. 2017, 317, 861-900. [CrossRef]

35. Zhang, S.C.; Wang, X.M.; Wang, H.J.; Bjerrum, C.J.; Hammarlund, E.U.; Costa, M.M.; Connelly, J.N.; Zhang, B.M.; Su, J.; Canfield, D.E. Sufficient oxygen for animal respiration 1,400 million years ago. Proc. Nat. Acad. Sci. USA 2016, 113, 1731-1736. [CrossRef]

36. Wang, H.J.; Ye, Y.T.; Deng, Y.; Wang, X.M.; Hammarlund, E.U.; Fan, H.F.; Canfield, D.E.; Zhang, S.C. Iron isotope evidence for a dynamic marine Fe cycle 1.4 Ga. Geochem. Perspect. Let. 2021. under review.

37. Fan, W.B. Geological features and research progress of the Mesoproterozoic Xiamaling Formation in the North China Craton: A review after nearly one hundred years of study. Geol. Rev. 2015, 61, 1383-1406. (In Chinese)

38. Wang, H.J.; Zhang, S.C.; Ye, Y.T.; Wang, X.M.; Zhou, W.X.; Su, J. In situ imaging of multi-elements on pyrite using laser ablation-inductively coupled plasma-mass spectrometry. Chinese J. Anal. Chem. 2016, 44, 1665-1670. [CrossRef]

39. Ye, Y.; Wang, H.; Wang, X.; Zhai, L.; Wu, C.; Zhang, S. In situ rare earth element analysis of a lower Cambrian phosphate nodule by LA-ICP-MS. Geol. Mag. 2020, 158, 749-758. [CrossRef]

40. Ye, Y.; Wang, H.; Wang, X.; Zhai, L.; Wu, C.; Zhang, S. Elemental geochemistry of lower Cambrian phosphate nodules in Guizhou Province, South China: An integrated study by LA-ICP-MS mapping and solution ICP-MS. Palaeogeogr. Palaeocl. 2020, 538, 109459. [CrossRef]

41. Planavsky, N.J.; McGoldrick, P.; Scott, C.T.; Li, C.; Reinhard, C.T.; Kelly, A.E.; Chu, X.L.; Bekker, A.; Love, G.D.; Lyons, T.W. Widespread iron-rich conditions in the mid-Proterozoic ocean. Nature 2011, 477, 448-451. [CrossRef] [PubMed] 
42. Wang, H.; Zhang, Z.; Li, C.; Algeo, T.J.; Cheng, M.; Wang, W. Spatiotemporal redox heterogeneity and transient marine shelf oxygenation in the Mesoproterozoic ocean. Geochim. Cosmochim. Acta 2020, 270, 201-217. [CrossRef]

43. Lyons, T.W.; Severmann, S. A critical look at iron paleoredox proxies: New insights from modern euxinic marine basins. Geochim. Cosmochim. Acta 2006, 70, 5698-5722. [CrossRef]

44. Holland, H.D. The oceans; a possible source of iron in iron-formations. Econ. Geol. 1973, 68, 1169-1172. [CrossRef]

45. Li, W.Q.; Beard, B.L.; Johnson, C.M. Biologically recycled continental iron is a major component in banded iron formations. Proc. Nat. Acad. Sci. USA 2015, 112, 8193-8198. [CrossRef] [PubMed]

46. Zhang, S.; Wang, H.; Wang, X.; Ye, Y. The Mesoproterozoic Oxygenation Event. Sci. China Earth Sci. 2021, 64, 1-26. [CrossRef]

47. Canfield, D.E.; van Zuilen, M.A.; Nabhan, S.; Bjerrum, C.J.; Zhang, S.; Wang, H.; Wang, X. Petrographic carbon in ancient sediments constrains Proterozoic Era atmospheric oxygen levels. Proc. Nat. Acad. Sci. USA 2021, 118, e2101544118. [CrossRef]

48. Tang, D.; Ma, J.; Shl, X.; Lechte, M.; Zhou, X. The formation of marine red beds and iron cycling on the Mesoproterozoic North China Platform. Am. Miner. 2020, 105, 1412-1423. [CrossRef]

49. Tosti, F.; Riding, R. Fine-grained agglutinated elongate columnar stromatolites: Tieling Formation, ca 1420 Ma, North China. Sedimentology 2017, 64, 871-902. [CrossRef]

50. Saltzman, M.R.; Thomas, E. Carbon Isotope Stratigraphy. In The Geologic Time Scale; Gradstein, F.M., Ogg, J.G., Ogg, M.S.G., Eds.; Elsevier: Oxford, UK, 2012; pp. 207-232.

51. Canfield, D.E.; Thamdrup, B. Towards a consistent classification scheme for geochemical environments, or, why we wish the term 'suboxic' would go away. Geobiology 2009, 7, 385-392. [CrossRef]

52. Tribovillard, N.; Algeo, T.J.; Lyons, T.; Riboulleau, A. Trace metals as paleoredox and paleoproductivity proxies: An update. Chem. Geol. 2006, 232, 12-32. [CrossRef]

53. Strakhovenko, V.; Subetto, D.; Ovdina, E.; Belkina, N.; Efremenko, N. Distribution of Elements in Iron-Manganese Formations in Bottom Sediments of Lake Onego (NW Russia) and Small Lakes (Shotozero and Surgubskoe) of Adjacent Territories. Minerals 2020, 10, 440. [CrossRef]

54. Fang, H.; Tang, D.; Shi, X.; Lechte, M.; Yu, W. Manganese-rich deposits in the Mesoproterozoic Gaoyuzhuang Formation (ca. 1.58 Ga), North China Platform: Genesis and paleoenvironmental implications. Palaeogeogr. Palaeocl. 2020, 559, 109966. [CrossRef]

55. Ye, L.; Fan, D.; Yang, P. Characteristics of manganese ore deposits in China. Ore. Geol. Rev. 1988, 4, 99-113.

56. Mei, M.; Yang, F.; Gao, J.; Meng, Q. Glauconites formed in the high-energy shallow-marine environment of the Late Mesoproterozoic: Case study from Tieling Formation at Jixian Section in Tianjin, North China. Front. Earth Sci. 2008, 15, 146-158. [CrossRef]

57. Qiao, X. Investigation on stratigraphy of the Qingbaikou Group of the Yanshan Mountains, North China. Chinese J. Geol. 1976, 3, 246-264. (In Chinese)

58. Weibel, R.; Lindström, S.; Pedersen, G.; Johansson, L.; Dybkjaer, K.; Whitehouse, M.; Boyce, A.; Leng, M. Groundwater table fluctuations recorded in zonation of microbial siderites from end-Triassic strata. Sediment. Geol. 2016, 342, 47-65. [CrossRef] 